\title{
Social Fiqh and Its Implications for Community Life in Society 5.0
}

\author{
Arbanur Rasyid \\ Institut Agama Islam Negeri Padangsidimpuan -Indonesia \\ arbanurrasyid@iain-padangsidimpuan.ac.id
}

\begin{abstract}
This paper aims to analyze and examine the developmental model of social fiqh in the era of society 5.0 and its implications for the social life of modern society in the 21st century AD. The research method uses a literature review by collecting various appropriate and supportive literature on social fiqh studies, such as the works of $\mathrm{KH}$ Sahal Mahfudz and KH Ali Yafi. The study results show that social figh in the 5.0 era will increase the ease of access and progress in people's lives concerning social, cultural, economic, and political issues by prioritizing the values of the public benefit. The development of social fiqh in the era of society 5.0 is a step to alleviate the increasingly complex problems of the people. Social fiq $h$ also educates and guides humans to become advanced, independent, prosperous, tolerant, moderate, balanced, and just human beings.
\end{abstract}

Keyword: $\quad$ social fiqh; society 5.0; life implications; community

\section{[]}

Tulisan ini bertujuan untuk menganalisis dan mengkaji model perkembangan fiqh sosial di era masyarakat 5.0 dan implikasinya bagi kehidupan sosial masyarakat modern di abad 21 Masehi. Metode penelitian menggunakan studi pustaka dengan mengumpulkan berbagai literatur yang sesuai dan mendukung kajian fiqh sosial, seperti karya-karya $\mathrm{KH}$ Sahal Mahfudz dan KH Ali Yafi. Hasil kajian menunjukkan bahwa fiqh sosial di era 5.0 akan meningkatkan kemudahan akses dan kemajuan kehidupan masyarakat yang menyangkut masalah sosial, budaya, ekonomi, dan politik dengan mengutamakan nilainilai kemaslahatan umum. Perkembangan fiqh sosial di era society 5.0 merupakan langkah untuk mengentaskan permasalahan umat yang semakin kompleks. Fiqh sosial juga mendidik dan membimbing manusia menjadi manusia yang maju, mandiri, sejahtera, toleran, moderat, seimbang, dan adil.

Kata kunci: fiqh sosial; era society 5.0; implikasi kehidupan; masyarakat 
Arbanur Rasyid

\section{Introduction}

The life that runs dynamically is in line with the emergence of complex problems. Various necessities of life will cause social, economic, cultural, educational, and even political problems. It becomes a reality that each era has its orientation. Humans are challenged to adapt to various characters from changing times quickly. The era of society 5.0 is a new era that modern humans must go through. This era is a concept coined by the Japanese government. The concept of society 5.0 rests on the manufacturing factor and solves social problems with the help of the integration of physical and virtual spaces. ${ }^{1}$

The rapid development of technology makes human needs more religious and goes hand in hand with the problems of religious life. According to alQardawī, the need for fatwas in modern life is not an act of playing games and breaking the law. Some people want the guidance of Islam to be practiced in daily life that is involved in various fields of modern life with various aspects. ${ }^{2}$ Thus, the study of fiqh needs to be opened more broadly by paying attention to aspects of society's main problems. The role of fiqh as a scientific discipline that gives birth to the law of a case must be more open to the times. The hope is that he can quickly provide alternative solutions to the problems and needs of modern society. To meet these demands, studying the latest fiqh science according to the situation and developments of the times is very necessary. ${ }^{3}$ In essence, how fiqh can make breakthroughs by giving birth to various legal products that are by the challenges of the times and the needs of society while still prioritizing the values of the teachings in the Qur'an and Sunnah. ${ }^{4}$ Adaptation to this change was made by al-Shāfi'i with the emergence of an old opinion (qawl qadìm) and a new opinion (qawljadìd). ${ }^{5}$

\footnotetext{
1 O.P. Skobelev and S. Yu Borovik, 'On the Way from Industry 4.0 to Industry 5.0; from Digital Manufacturing to Digital Society', Industry 4.0 2, no. 6 (2017): 307-11, https://stumejournals.com/ journals/i4/2017/6/307.full.pdf.

2 B. Khaeruman, 'Al-Qaradawi dan Orientasi Pemikiran Hukum Islam untuk Menjawab Tuntutan Perubahan Sosial', Jurnal Wawasan: Jurnal Ilmiah Agama dan Sosial Budaya 1, no. 2 (2016): 227-38, https://doi.org/10.15575/jw.v1i2.740.

${ }^{3}$ A. Nugroho, 'Rekontruksi Pemikiran Fikih: Mengembangkan Fikih Progresif-Revolusioner', AlManahij: Jurnal Kajian Hukum Islam 9, no. 1 (n.d.): 1-20.

${ }^{4}$ Abdul Manan, Aspek-Aspek Pengubah Hukum (Jakarta: Kecana, 2006).

5 Muhammad Ibn Idrīs Al-Shāfi'ī, Al-Umm, 1sted. (Beirut: Dār al-Kutub al-'Ilmiyyah, 2009), 31.
} 
Socially oriented fiqh needs to be developed and rebuilt. The goal is to provide solutions in alleviating various problems of human life. Social Fiqh is a context orientation of contemporary Indonesian fiqh. ${ }^{6}$ There have been many ideas and concepts of Indonesian fiqh offered by several Indonesian scholars. Hasbi ash-Shiddieqy, for example, relates fiqh thinking according to the social character of Indonesian society. ${ }^{7}$ Munawir Syadzali emphasizes the formulation of Islamic teachings by scholars with the social reality of Indonesian society. KH Sahal Mahfudz ${ }^{8}$ and KH Ali Yafie ${ }^{9}$ seek to transform Islamic teachings' values into the dimensions of individual and group life at the community and state levels. The critical point is for the benefit ${ }^{10}$ so that the thought and study of Islamic law are dynamic and can adapt to any changes. ${ }^{11}$ The two figures mentioned later have different pressure points. KH Sahal Mahfudz focuses more on the role and contribution of fiqh in the socioeconomic field and knits togetherness. ${ }^{12}$ Meanwhile, KH Ali Yafie focuses on efforts so that fiqh has the dimensions of worship and contextualizes its studies according to the challenges of the times. ${ }^{13}$

The reconstruction of social fiqh in the era of society 5.0 is essential to study. The aim is to find various alternative solutions to the legal needs of modern society in the 21 st century. Considering that social fiqh is a contextual fiqh formulation, the scope of its study is broad. ${ }^{14}$ It is not limited to the area of 'ubüdiyah but includes other areas. Social values that form the basis of

6 Juhaya S. Praja, "Dinamika Pemikiran Hukum Islam", dalam Jaih Mubarok, Sejarah dan Perkembangan Hukum Islam (Bandung: Rosdakarya, 2001), 91.

7 T.M. Hasbi Ash-Shiddieqiy, Syariat Islam Menjawab Tantangan Zaman (Jakarta: Bulan Bintang, 1966), 43.

8 Muhammad Ahmad Sahal Mahfudz, Nuansa Fikih Sosial (Yogyakarta: LKis, 1994).

${ }^{9}$ Ali Yafie, Menggagas Fikih Sosial (Bandung: Mizan, 1994), 23-24.

10 Masdar Farid Mas'udi, Agama Keadilan: Risalah Zakat (Pajak) dalam Islam (Jakarta: LP3M, 1991), 76.

11 Mahsun Fuad, Hukum Islam Indonesia: Dari Nalar Partisipatoris Hingga Emansipatoris (Yogyakarta: LKiS, 2005), 62-63.

12 Faisal, Ahmad. "Nuansa Fiqh Sosial KH. MA. Sahal Mahfudh." Al-Ulum 10.2 (2010): 363-382.

13 Fathorrahman, Fathorrahman. "Pandangan Fikih Sosial KH Ali Yafie dan Kontribusinya terhadap Kajian Pembangunan di Indonesia." Asy-Syir'ah: Jurnal Ilmu Syari'ah dan Hukum 50.2 (2016): 355-378.

14 Mujammil Qomar, Nu "Liberal": Dari Tradisionalisme Ahlussunnah ke Universalisme Islam (Bandung: Mizan, 2002); Ahmad Rofiq, Fikih Kontekstual: Dari Normatif ke Pemaknaan Sosial (Yogyakarta: Pustaka Pelajar, 2012). 
Arbanur Rasyid

universal values in people's lives, the changing times with all their social phenomena, and aspects of development form the basis for the government to develop social science and studies in Indonesia. These three are the primary concern in studying social fiqh.15

There are three strategies so that fiqh can adapt to any changes. ${ }^{16}$ First, the integration and interconnection of social values. ${ }^{17}$ Second, the spirit of changing times. ${ }^{18}$ Third, the government's development policy ${ }^{19}$ into social fiqh. The framework and concepts of social fiqh used to examine contemporary issues, and government policies related to social, cultural, political, and religious life are viewed from a normative-positivistic perspective. However, the government will take the dynamic-dialectical and contextualist elements that cover the background of the presence of problems in people's lives and the policy formulation process to overcome these problems. It is an effort to balance goals, interests, processes, and benefits in line with universal values in the form of usefulness. ${ }^{20}$

This research is qualitative, with the data source in the form of a library. ${ }^{21}$ Data collection is obtained by processing various documents found, either in notes or articles, according to the research object. ${ }^{22}$ Furthermore, the data is analyzed and described so that a map and flow of the reconstruction process of social fiqh in society 5.0 is found and its implications for modern human life.

15 Abdurrahman Wahid, Islam Kosmopolitan: Nilai-Nilai Indonesia dan Tranfromasi Kebudayaan (Jakarta: The Institute, 2007), 44-62.

16 Cik Hasan Basri, Pilar-Pilar Penelitian Hukum Islam dan Pranata Sosial (Jakarta: Rajawali Pers, 2004), 42.

17 Tariq Ramadhan, Menjadi Modern Bersama Islam: Islam, Barat, dan Tantangan Modernitas, terj. Zubair dan Ilham (Bandung: Teraju Mizan, 2003), 37-38.

18 Zubaidi, Pemberdayaan Masyarakat Berbasis Pesantren: Kontribusi Fikih Sosial Sahal Mahfudz dalam Perubahan Nilai-Nilai Pesantren (Yogyakarta: Pustaka Pelajar, 2007), 92.

19 Masruhan, 'Pemikiran Kyai NU tentang Relasi Agama dan Negara', Jurnal Al-Qanun 12, no. 1 (2009): 90, https://doi.org/10.15642/alqanun.2009.12.1.78-105.

20 Fathorrahman, 'Pandangan Fikih Sosial KH. Ali Yafie dan Kontribusinya terhadap Kajian Pembangunan Indonesia', Asy-Syir'ah: Jurnal Ilmu Syari'ah dan Hukum 50, no. 2 (2016): 358, http://dx.doi.org/10.14421/asy-syir'ah.2016.502-03.

21 Suharsimi Arikunto, Prosedur Penelitian Suatu Pendekatan Praktis (Jakarta: Rineka Cipta, 2002), 34. Amir Hamzah, Metode Penelitian Kualitatif(Malang: Literasi Nusantara, 2019), 269

22 Moh. Nizar, Metode Penelitian (Bogor: Ghalia Indonesia, 2005), 111. L. Cohen and et.al, Research Method in Education (New York: Routledge, 2011), 104. 


\section{The existence of Social Fiqh in the Era of Society 5.0}

Era 5.0 is the era of human resource development, socio-economic independence, and improvement of living standards while upholding morality, solidarity, and social responsibility. Social fiqh is present as a form of Islamic legal responsibility in solving people's problems by providing alternative ways, according to the conditions and situations. Social fiqh is a contextual reaction to the dynamics of the times to be more productive and reactive to social welfare, economy, human development, independence, and other human needs. ${ }^{23}$ It means that social fiqh is needed to answer worship problems and contribute to the welfare of the people in terms of social, economic, cultural, and educational aspects.

Fiqh is presented as social ethics and spiritual ethics, identical to community development, especially in cultural, social, economic, and political issues. The meaning of social fiqh can refer to its original meaning. Abū Hanifah explained that fiqh is self-knowledge about what is good and wrong, or what is beneficial to humans and what is harmful (madarāt) to them..$^{24}$

$\mathrm{KH}$ Sahal Mahfudh is one of the initiators of social fiqh. It is intended to reference the fundamental values of fiqh in human life, which is constantly changing. It requires a paradigm shift in the field of fiqh. It means that KH Sahal strives to continue to update the existence of fiqh so that it can provide real solutions and contributions to the community's needs from time to time. ${ }^{25}$ This idea can empower the enrichment of fiqh studies as one of the drivers of contextual diversity in people's lives and strengthen the joints of fiqh science. Of course, with the core spirit of forming and achieving benefit in people's lives. Thus, social fiqh will respond, adjust, and pay attention to the public, national, and social problems that develop in people's lives today. ${ }^{26}$ By understanding

\footnotetext{
${ }^{23}$ M. Fahim Khan, 'Fiqh Foundations of the Theory of Islamic Economics: A Survey of Selected Contemporary Writings on Economics Relevant Subjects of Fiqh', in Theoretical Foundations of Islamic Economics, ed. Habib Ahmed, 1st ed. (Jeddah: Islamic Development Bank Islamic Reseacrh and TrainingInstitute, 2002), 59-85, http://eprc.sbu.acir/File/Book/Theoretical foundations of islamic economics_47566.pdf.

${ }^{24}$ M. Imam Aziz, Belajar dari Kiai Sahal Mahfudh (Pati: Pengurus Pusat Keluarga Mathali'ul Falah PPKMF, 2014), 188.

25 J.M.M. Asmani, 'Fikih Sosial Kiai Sahal Sebagai Fikih Peradaban', Al-Ahkam 24, no. 1 (2014): 3146, https://doi.org/10.21580/ahkam.2014.24.1.130.

26 Djohan Efendi, Pembaruan Tanpa Membongkar Tradisi: Wacana Keagamaan di Kalangan Generasi Muda NU Masa Kepemimpinan Gus Dur (Jakarta: Kompas, 2010), 194-95.
} 
Kiai Sahal's line of thought regarding the concept of social fiqh, we will know the orientation and purpose of the social fiqh.

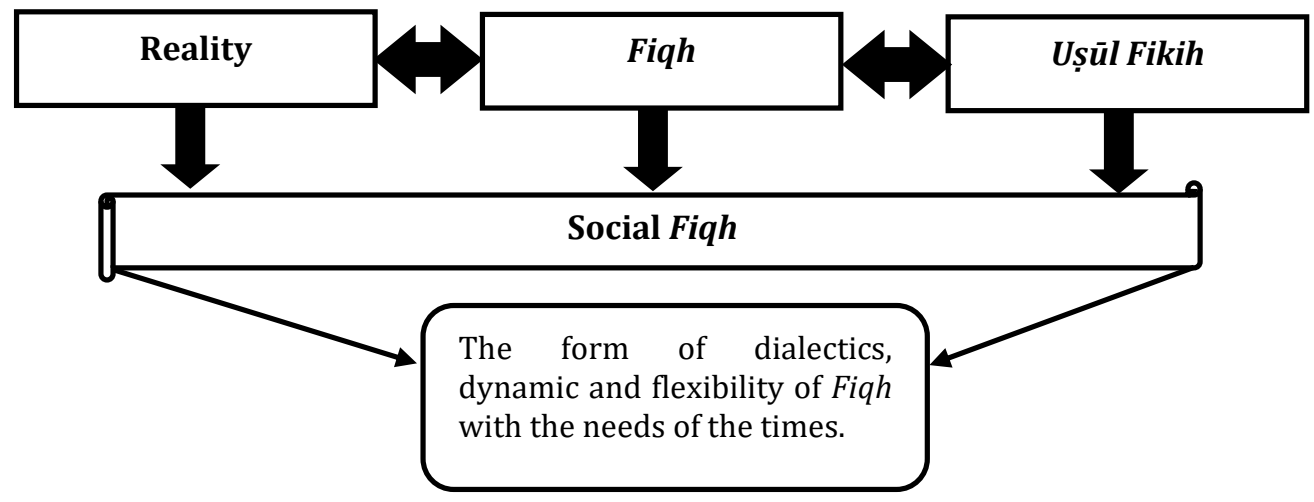

Figures 1: KH Sahal Mahfudh's social fiqh concept map

In figure 1 above, we can understand that social fiqh is a form of a dialectic between aspects of the reality of society, with fiqh as the legal basis and ushul fiqh as a source of law. The main goal is the benefit and interests of the people universally. In its practical form, social fiqh empowers the potential and skills of the community. Thanks to the three elements developed by Kiai Sahal, Islamic law, especially fiqh mu'ämalah, is not static but becomes fiqh that is responsive, dynamic, and adaptive to all conditions. ${ }^{27}$

Kiai Ali Yafie also expressed this idea through his concept of social fiqh. He tries to ground the concept of contextual fiqh in the form of fiqh that is not rigid, which only refers to the textual form of the texts. This effort is intended to prevent the study of fiqh from being trapped in a practice that only dwells on the ritual dimension of worship (mahdah). ${ }^{28}$ Thus, the nuances of fiqh will go hand in hand with the interests of the wider community. ${ }^{29}$ The social dimension that characterizes the scope of Kiai Ali Yafie's social fiqh study provides a feeling of flexibility and an atmosphere of adaptability in studying,

27 Mohammad Mahrussilah, 'Fikih Sosial Kiai Sahal Mahfudh: Pengembangan Kemandirian Ekonomi Pesantren dan Masyarakat', Jurnal Al Mizan 2, no. 2 (2018): 14, https://ejurnal.iiq.acid/ index.php/almizan/article/view/37/23.

${ }^{28}$ Fuad, Hukum Islam Indonesia: Dari Nalar Partisipatoris Hingga Emansipatoris.

${ }^{29}$ Akh. Minhaji, “Ushul Fikih dan Hemeneutika: Refleksi Awal”, dalam Muhyar Fanani, Ilmu Ushul Fiqih di Mata Filsafat Ilmu (Semarang: Walisongo Press, 2009). 
observing, and seeing various social problems in society so that ideas arise about social spirit without reducing the essence of Islamic teachings. 30

From this, it is known that to maintain the existence of figh, breakthroughs, new paradigms, and new approaches are needed to adapt to current conditions. We know that fiqh as a product of Islamic law is dynamic and flexible, so the steps to initiate and conceptualize social figh are very appropriate, especially in this era of society 5.0. Social fiqh, in this case, also upholds the concept of maqāsid shari'ah, which is a necessity. Given that, fiqh must be able to reach human benefit ${ }^{31}$ in order to be able to solve various problems in life, both in the social, political, economic, cultural, and educational dimensions.

The explanation of Husein Muhammad reinforces this analysis. He emphasized that the idea of social fiq $h$ and its existence pioneered by Kiai Sahal could create human morality. In his view, he states that fiqh is "social ethics" not as "state law". He emphasized that fiqh must be a study of social ethics for the benefit and interest of the general public, not as a product used to punish others. The conception of fiqh as social ethics is the culmination of a series of reflections and profound meanings of the term "social fiqh".32

The existence of social fiqh in the 5.0 era will increase the ease of access and progress in people's lives while still prioritizing the values of nobility, benefit, and public interest. Do not become a society that "justifies" all means for personal gain, egoism, and a materialistic hedonist paradigm coupled with secular and liberal attitudes. Social fiqh exists to protect, assist, and direct the right things according to religious guidance. Social fiqh is not educating modern humans with a selfish mentality, but a modern society that is tolerant, peaceful, and cooperative to raise all social problems that generally suppress human life. ${ }^{33}$

30 Yafie, Menggagas Fikih Sosial. Muhtar Gundaatmaja, Kontroversi Pemikiran Islam di Indonesia (Bandung: Rosdakarya, 993), 13-20. Jamal D. Rahmat, Wacana Baru Fiqih Sosial 70 Tahun KH. Ali Yafie (Bandung: Mizan, 1997). Muhammad, Dialog dengan Kiai Ali Yafie (Yogyakarta: IRCiSoD, 2020).

${ }^{31}$ Asmani, 'Fikih Sosial Kiai Sahal Sebagai Fikih Peradaban'. Zuhairi Misrawi, Menggugat Tradisi: Pergulatan Pemikiran Anak Muda NU (Jakarta: Kompas-P3M, 2004), 59. Yasin Asmuni, Ijtihād Wa ITahqiq (Kediri: Hidayah al-Thullab, t.t, n.d.), 3-10.

32 Muhammad Khalid Mas'ud, 'Ikhtilaf Al-Fuqaha: Diversity in Fiqh as a Social Construction', Musawa, 2009, https://arabic.musawah.org/sites/default/files/Wanted-MKM-EN.pdf.

33 M.A. Abd Muin, S. Abdullah, and A.C. Omar, The Fiqh Method in Islamic Social Entrepreneurship an Introduction in Islamic Development Management (Singgapore: Spinger, n.d.), 225-38. 
Arbanur Rasyid

The explanation above shows that the concept of social fiqh in terms of orientation and purpose is almost the same as the concept of society 5.0. Both of them lead to the order of social life. Every existing challenge can be solved by combining innovations from various elements contained in the 4.0 industrial revolution. Through social revolution 5.0, artificial intelligence that pays attention to humanity will transform millions of data collected through the internet in all areas of life. Of course, it is expected to be new wisdom in the social order. It is remembering that this transformation will help humans to live more meaningful lives. In society, 5.0 emphasizes the aspect of balancing economic achievements with solving social problems. ${ }^{34}$

Social fiqh must be understood as a process of ijtihād. The dialectic between existing doctrine and reality was developed in society 5.0, which is more contextual. The urgency lies in creating a new perspective on fiqh that accommodates the flow of change and various social realities that emerged in the era of society 5.0. Social reality needs to be accommodated by fiqh views. Ibn Taimiyah states that fundamental issues related to the daily life of Muslims must be considered, not formalistic scholastic issues which will only have a rigid and normative appearance. 35 For this reason, social fiqh is a step to flex the discipline of fiqh and its legal studies.

\footnotetext{
34 Mayumi Fukuyama, 'Society 5.0: Aiming for New Human Centered Society', Japan Spotlight 27 (2018): 47-50, https://www.jef.or.jp/journal/pdf/220th_Special_Article_02.pdf; Yoshihiro Shiroishi, Kunio Uchiyama, and Norihiro Suzuki, 'Society 5.0: For Human Security And Well-Being', Computer 51, no. 7 (2018): 91-95, https://doi.ieeecomputersociety.org/10.1109/MC. 2018.3011041; Hisny Fajrussalam, Agus Salim Mansyur, and Qiqi Yuliati Zaqiah, 'Gaining Education Character Based on Cultural Sundanese Values: The Innovation of Islamic Education Curriculum in Facing Era Society 5.0', Jurnal Iqra': Kajian Ilmu Pendidikan 5, no. 1 (2020): 104-19, https://doi.org/10.25217/ji.v5i1.910; Handry Yoga Raharja, 'Relevansi Pancasila Era Industry 4.0 dan Society 5.0 di Pendidikan Tinggi Vokasi', Journal of Digital Education, Communication, and Arts (Deca) 2, no. 1 (2019): 11-20, https://doi.org/10.30871/deca.v2i1.1311.

35 Muhammad Amin, Ijtihād Ibnu Taimiyah dalam Bidang Fikih Islam (Jakarta: INIS, 1991), 27.
} 
Social Fiqh and Its Implication ...

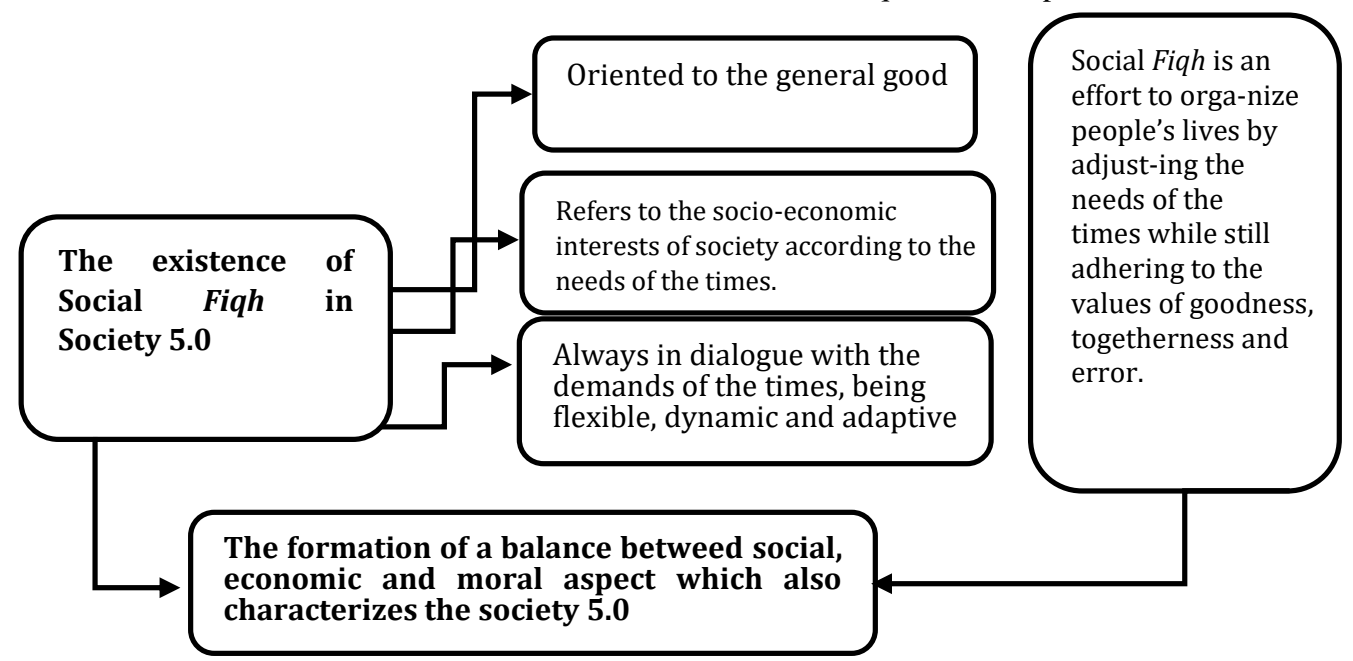

Figure 2: The existence of social fiqh in society 5.0

\section{Reconstruction of Social Fiqh in Society 5.0 Era and Its Implications}

Social fiqh has five main characteristics as follows:

1. The contextual interpretation of fiqh texts.

2. Changing the pattern of schools of thought from textual to methodological (madhhab, manhaj).

3. Verification between the original case ( $u s ̦ \bar{u} l)$ and the new case (far').

4. Fiqh is presented as a social ethic, not a positive law of a country.

5. The introduction of the methodology of philosophical thought, especially in cultural and social, and economic issues. ${ }^{36}$

Social fiqh is a representation of Islamic teachings that are flexible and dynamic. Social fiqh is always able to dialogue with all the demands of the times to answer the needs of the global community. Fiqh must continue to be updated and developed by the direction of the times. By reconstructing social fiqh in society 5.0, it is hoped that fiqh can universally answer various needs, challenges, and interests of the community.

36 Mahfudz, Nuansa Fikih Sosial, 36; Abd Muin et al., The Fiqh Method In Islamic Social Entrepreneurship: An Introduction, Islamic De (Singapore: Springer, 2019), 225-38; Deina Abdelkader, Social Justice in Islam (USA: The International Institute of Islamic Thought, 2000). 
Arbanur Rasyid

These efforts were carried out by updating old fiqh concepts and then adjusting them to the needs of each era. The orientation and focus of social fiqh are more on cultural, social, economic, and political aspects, with the initial formulation. Through this orientation, social fiqh can be reconstructed into a more comprehensive study to meet the needs of people's lives from all aspects.

The reconstruction of social fiqh in the era of society 5.0 is expected to inspire the concepts and paradigms of Islamic law to be more responsive, solutions, innovative and creative in responding to various problems of modern life. Social fiqh is expected to be an alternative and community choice in solving all their life needs. It needs to be done because the problems and needs of the community are increasingly complex. The orientation of social fiqh does not only revolve around the issue of right and wrong, haram and wajib, sunnah and makruh but is broader than that. The problem of economic, social, cultural, humanitarian, educational, and political inequality is the subject of social fiqh. For this reason, in the era of society 5.0, which is oriented towards improving the quality of human resources supported by high morality, this will be a strategic moment in rebuilding the concepts and ideas of social fiqh.

Efforts to bring up a new perspective in fiqh are part of the appreciation of the legal experts of the past inheritance. This step attempts to create responsive and contextual legal formulations and theories that are in line with socio-cultural developments that demand a new paradigm ${ }^{37}$ The reconstruction of social fiqh begins to manifest its adaptive nature so that it is permanently attached to the ijtihād process in Islamic law. The main reason is that the existing reality often shows that society's development and public opinion are running more dynamically and faster than the development of the legal community itself. 38

The main implication of the reconstruction of social fiqh is to create universal values, namely the benefit and welfare of humans. Ibn Taimiyah, in this case, states that the existence of fiqh is to create benefit and reject various forms of damage and evil. ${ }^{39}$ Fiqh, as a formulation of sharia understanding, has two objectives. First, build the behavior of every Muslim based on faith, sharia,

\footnotetext{
${ }^{37}$ Aḥmad Muḥammad Al-Zarqā, Sharḥ al-Qawāilid al-Fiqhiyah (Dār al-Qalam, 1938), 173.

38 Șubḥi Maḥmașānī, Falsafah al-Tashrī' fi al-Islām (Beirut: Dār al-'Ilm, 1961); Ahmad Hasan, The Early Development of Islamic Jurisprudence (Islamabad: Islamic Research Institute, 1970).

39 'Abd al-Rahmān Ibn Muhammad Ibn Qāsim Al-'Āṣimī, Majmū' Fatāwā Shaykh al-Islām Ibn Taymiyah (Wizārah al-Shu'ūn al-Islāmiyah wa al-Da'wah wa al-Irshād al-Su'ūdiyah, n.d.), 20.
} 
and morals. Second, realizing the order of social life in society with the identity of justice, equality, and partnership. The second goal is to form a social attitude that seeks to respond to changing times and problems to free people from the inequality of life, build welfare, and increase a sense of solidarity and equitable justice. Social fiqh seeks to transform Islamic values into social attitudes that can provide benefits to fellow human beings. Thus, Muslims are not inclusive, rigid, selfish, and formal, but socialist, moderate, flexible, and wise.

Another implication of the reconstruction of fiqh in society 5.0 is to uphold the values of humanity, justice, welfare, economic prosperity, solidarity, and benefit. Social fiqh thus requires two piety at once, namely pious individually and pious socially. 40

The reconstruction of social fiqh in society in the era of society 5.0 is thus a concrete step to develop a broader study of fiqh in responding to the increasingly complex problems of the ummah. It not only orients ritual worship vertically but also social rituals horizontally. Social fiqh does not only regulate the relationship between humans and God, but the order between fellow humans, nature, and the state. Social fiqh studies are, of course, more comprehensive. The impact is the realization of a social life that is more humanist, socialist, ethical, and able to grow the progress of the ummah wisely while still using the religious foundation as a rail. So that human life becomes better.

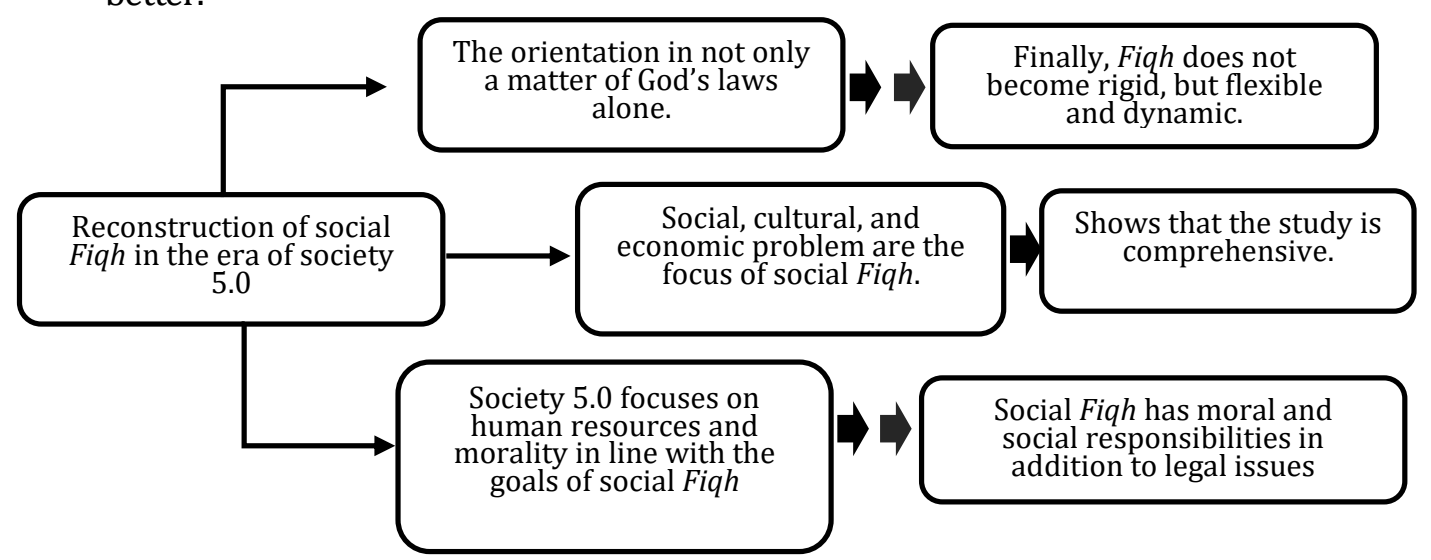

Figure 3: the reconstruction of social fiqh in society 5.0

40 Zubaedi, 'Membangun Fikih yang Berorientasi Sosial: Dialektika Fikih dengan Realitas Empirik Masyarakat', Al-Jami'ah 44, no. 2 (2006): 448, https://doi.org/10.14421/ajis.2006. 442.429-452. 
Arbanur Rasyid

\section{Contribution of Social Fiqh to the Social Life of Modern Society}

Social fiqh strives to provide an alternative way to the needs and demands of society at large. The social life of modern society is not based on material or hedonic paradigms. However, social life refers to the common good, partnering, uniting ( $t a^{\prime}$ âwun), working together to build a better civilization. ${ }^{41}$ Social fiqh provides various ways to form a stable society in heterogeneity, tolerant in plurality, moderate in different schools of thought, flexible in the dynamism of life, and sensitive in diverse needs. ${ }^{42}$

The social life of modern society is inseparable from problems and different lifestyles and wild paradigms that sometimes affect lifestyle and behavior. Social fiqh plays its role in providing direction to be able to live in a good society. It also provides a perspective to act according to Islamic teachings by not following external paradigms that deviate from Islamic teachings. The paradigm that develops in modern society, which is adopted from outside contrary to Islamic religious values, must be avoided. Social figh, in this case, serves as a filter for these negative influences. ${ }^{43}$

Another contribution of social fiqh to the community's social life is to participate in educating and guiding the community to become advanced, independent, and prosperous human beings. This contribution is made in the following ways. 1. Provide solutions and concepts on how to build an advanced people's economy. ${ }^{44}$ Building social partners who help each other (sharia cooperatives), 3. It provides various legal fatwas that facilitate the socioeconomic affairs of the community.45 4. Optimizing the role of zakat, waqf, and infaq for the welfare of the wider community. 5. Strengthening sharia banking in Indonesia for the ummah's convenience, convenience, and independence,

\footnotetext{
41 Y. Sopyan, 'Corporate Social Responsibility (CSR) sebagai Implementasi Fikih Sosial untuk Pemberdayaan Masyarakat', AHKAM: Jurnal Ilmu Syariah 14, no. 1 (2014), http://dx.doi.org/10. 15408/ajis.v14i1.1253.

42 Mahfudz, Nuansa Fikih Sosial.

43 Idri I, 'Pengenalan Metodologi Filosofis dalam Kajian Fikih Budaya dan Sosial', KARSA: Journal of Social and Islamic Culture 20, no. 2 (2013): 165-75, https://doi.org/10.19105/ karsa.v20i2.40.

${ }^{44}$ S. Santoso, Konsep Corporate Social Responsibility dalam Perspektif Konvensional dan Fiqh Sosial (Tulunggaung: State Islamic Institute of Tulungagung, 2016).

45 A. Syukur, 'Revitalisasi Ilmu Fiqh di Pesantren: Agenda Memperkuat Kontribusi Terhadap Ekonomi Islam di Indonesia', Qawãnïn: Journal of Economic Syaria Law 2, no. 2 (2018), https://doi.org/10.30762/q.v2i2.1043.
} 
especially Muslims. 6. Educate the community to be a tolerant, moderate, balanced, and just society. 46

Some of the contributions of the conception of social figh in the era of society 5.0 above can be translated into several aspects. 1. Community economic empowerment. 2. Granting the right to freedom of religion and belief. 3. Educate moderate religion, 4-train social sensitivity between individuals. ${ }^{47}$ Thus, the role and contribution of social fiqh in the era of society 5.0 is vital and needs to be supported by various government policies and elements of society to jointly make a positive contribution to the social life of modern society in this century.48

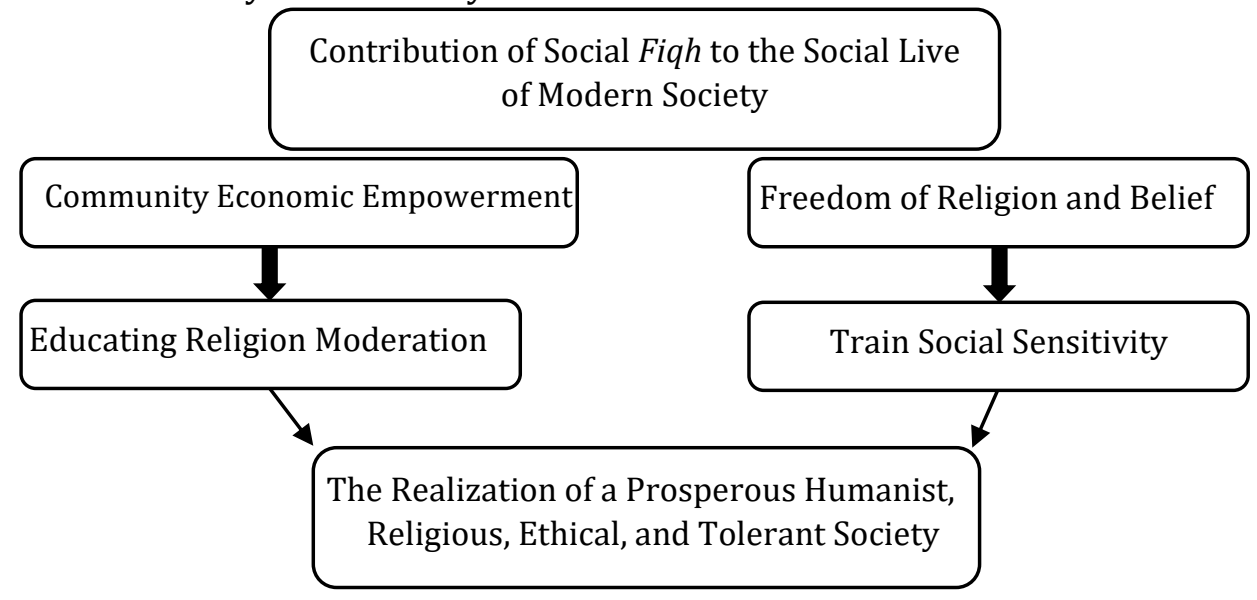

Figure 4: The contribution of social Fiqh to the social life of modern society

Figure 4 above shows that social fiqh makes a significant contribution to aspects of human life. For example, in economic matters, about sharia economics, the legality of creative economy development, and the ease of conducting economic transactions. ${ }^{49}$ In terms of freedom in choosing beliefs

\footnotetext{
46 A. B. Rusli, 'Nalar Ushul Fiqh KH. Sahal Mahfudh dalam Wacana Islam Indonesia', Potret Pemikiran 22, no. 2 (2018), http://dx.doi.org/10.30984/pp.v22i2.785.

47 N. Fauza, 'Fikih Inklusif dalam Konteks Multikulturalisme Sosial Keagamaan Masyarakat Indonesia (Studi Pemikiran KH. Abdul Qodir AF)', At-Tahdzib: Jurnal Studi Islam dan Muamalah 6, no. 2 (2018): 94-114, http://ejournal.kopertais4.or.id/mataraman/index.php/tahdzib/article/view/ $3575 / 2706$.

48 Y. D. Sanrego and M Taufik, Fiqih Tamkin: Membangun Modal Sosial dalam Mewujudkan Khairu Ummah (Jakarta: Qisthi Press, 2016).

${ }^{49}$ Khotibul Umam, 'Legislasi Fikih Ekonomi Perbankan: Sinkronisasi Peran Dewan Syariah Nasional dan Komite Perbankan Syariah', Mimbar Hukum 24, no. 2 (2012): 357-75,
} 
Arbanur Rasyid

and truths, for example, social fiqh supports the concept of religious moderation; there is no compulsion in religion, adherents of other religions must still be treated well and humanely. ${ }^{50}$ In addition, it also provides a moderate pattern of religious education, such as tolerance, pluralism. ${ }^{51}$ Lastly, educate the public to be sensitive to social issues, such as generosity, empathy, sympathy, socialism, and society. ${ }^{2}$

\section{Conclusion}

Social fiqh must be understood as a process of ijtihād. The dialectic between doctrine and reality can be heard again in the contextual era. The reconstruction of social fiqh in the era of society 5.0 is a concrete step to develop a broader study of fiqh in alleviating the increasingly complex problems of the people. It is no longer only oriented to ritual worship vertically, but also horizontally so that it has a positive impact, namely the realization of a more humanist, socialist, ethical, and spiritual social life that can foster the progress of the people wisely, in this case, it can be called the paradigm-social fiqh 5.0. The role of social fiqh, in addition to providing direction to be able to live in society well, also provides a perspective to act according to Islamic teachings by not following external paradigms that deviate from Islamic teachings and educating and guiding people to become independent and

https://doi.org/10.22146/JMH.16139; Azwar Iskandar, Bayu Taufiq Possumah, and Khaerul Aqbar, 'Peran Ekonomi dan Keuangan Sosial Islam Saat Pandemi Covid-19', Salam: Jurnal Sosial dan Budaya Syar-I 7, no. 7 (25 May 2020): 625-38, https://doi.org/10.15408/SJSBS.V7I7.15544; Muh. Irhas Darojat, 'Peran KH. MA. Sahal Mahfudh dalam Pemberdayaan Ekonomi Masyarakat' (Universitas Islam Negeri Walisongo Semarang, 2018), http://eprints.walisongo.ac.id/9947/.

50 Choirul Anwar, 'Islam dan Kebhinekaan di Indonesia: Peran Agama dalam Merawat Perbedaan', Zawiyah: Jurnal Pemikiran Islam 4, no. 2 (27 December 2018): 1-18, https://doi.org/10.31332/ZIPI.V4I2.1074; Abu Bakar Djafar, 'Peran Agama dalam Merawat Perbedaan (Islam dan Kebhinekaan di Indonesia)', Prosiding Seminar Nasional LKK 1, no. 1 (13 March 2020), http://openjournal.unpam.acid/index.php/psnlkk/article/view/4634; Mahmud Arif, 'Islam Humanis, HAM, dan Humanisasi Pendidikan: Eksposisi Integratif Prinsip Dasar Islam, Kebebasan Beragama, Kesetaraan Gender, dan Pendidikan Humanis', Musãwa Jurnal Studi Gender dan Islam 15, no. 2 (17 July 2016): 233-47, https://doi.org/10.14421/MUSAWA.V15I2.1307.

${ }^{51}$ Abdul Syatar Abdul Syatar et al., 'Darurat Moderasi Beragama di Tengah Pandemi Corona Virus Desease 2019 (Covid-19)', KURIOSITAS: Media Komunikasi Sosial dan Keagamaan 13, no. 1 (2 June 2020): 1-13, https://doi.org/10.35905/KUR.V13I1.1376.

52 Muhammad Ahnu Idris, Taufik Taufik, and Bahrur Rosi, “'Dakwah Pembebasan” Perspektif KH. MA. Sahal Mahfudh dalam Buku "Nuansa Fiqih Sosial", Ulumuna: Jurnal Studi Keislaman 6, no. 1 (15 June 2020):35-52, https://doi.org/10.36420/JU.V611.3702. 
prosperous, tolerant, moderate, and progressive human beings—-balanced and fair.[a]

\section{BIBLIOGRAPHY}

Abdelkader, Deina. Social Justice in Islam. USA: The International Institute of Islamic Thought, 2000.

Amin, Muhammad. Ijtihad Ibnu Taimiyah dalam Bidang Fikih Islam. Jakarta: INIS, 1991.

Anwar, Choirul. 'Islam dan Kebhinekaan di Indonesia: Peran Agama dalam Merawat Perbedaan'. Zawiyah: Jurnal Pemikiran Islam 4, no. 2 (27 December 2018): 1-18. https://doi.org/10.31332/ZJPI. V4I2.1074.

Arif, Mahmud. 'Islam Humanis, HAM, dan Humanisasi Pendidikan: Eksposisi Integratif Prinsip Dasar Islam, Kebebasan Beragama, Kesetaraan Gender, dan Pendidikan Humanis'. Musãwa Jurnal Studi Gender dan Islam 15, no. 2 (17 July 2016): 233-47. https://doi.org/10.14421/MUSAWA.V15I2.1307.

Arikunto, Suharsimi. Prosedur Penelitian Suatu Pendekatan Praktis. Jakarta: Rineka Cipta, 2002.

Ash-Shiddieqiy, T.M. Hasbi. Syariat Islam Menjawab Tantangan Zaman. Jakarta: Bulan Bintang, 1966.

Al-'Āṣimī, 'Abd al-Raḥmān Ibn Muhammad Ibn Qāsim. Majmū' Fatāwā Shaykh al-Islām Ibn Taymiyah. Wizārah al-Shu'ūn al-Islāmiyah wa al-Da'wah wa al-Irshād al-Su'ūdiyah, n.d.

Asmani, J.M.M. 'Fikih Sosial Kiai Sahal sebagai Fikih Peradaban'. AlAhkam 24, no. 1 (2014): 31-46. https://doi.org/https://doi.org/ 10.21580/ahkam.2014.24.1.130.

Asmuni, Yasin. Al-Ijtihād wa al-Taqlīd. Kediri: Hidayah al-Thullab, n.d.

Aziz, M. Imam. Belajar dari Kiai Sahal Mahfudh. Pati: Pengurus Pusat Keluarga Mathali'ul Falah PPKMF, 2014.

Basri, Cik Hasan. Pilar-Pilar Penelitian Hukum Islam dan Pranata Sosial. Jakarta: Rajawali Pers, 2004.

Cohen, L., and et.al. Research Method in Education. New York: Routledge, 2011. 
Darojat, Muh. Irhas. 'Peran KH. MA. Sahal Mahfudh dalam Pemberdayaan Ekonomi Masyarakat'. Universitas Islam Negeri Walisongo Semarang, 2018. http://eprints.walisongo.ac.id/ 9947/.

Djafar, Abu Bakar. 'Peran Agama dalam Merawat Perbedaan (Islam dan Kebhinekaan di Indonesia)'. Prosiding Seminar Nasional LKK 1, no. 1 (13 March 2020). http://openjournal.unpam.ac.id/index.php/ psnlkk/article/view/4634.

Efendi, Djohan. Pembaruan Tanpa Membongkar Tradisi: Wacana Keagamaan di Kalangan Generasi Muda NU Masa Kepemimpinan Gus Dur. Jakarta: Kompas, 2010.

Fajrussalam, Hisny, Agus Salim Mansyur, and Qiqi Yuliati Zaqiah. 'Gaining Education Character Based on Cultural Sundanese Values: The Innovation of Islamic Education Curriculum in Facing Era Society 5.0'. Jurnal Iqra': Kajian Ilmu Pendidikan 5, no. 1 (2020): 104-19. https://doi.org/https://doi.org/10.25217/ji.v $5 i 1.910$.

Fanani, Muhyar. Ilmu Ushul Fiqih di Mata Filsafat Ilmu. Semarang: Walisongo Press, 2009.

Fathorrahman. 'Pandangan Fikih Sosial KH. Ali Yafie dan Kontribusinya Terhadap Kajian Pembangunan Indonesia'. Asy-Syir'ah: Jurnal Ilmu Syari'ah dan Hukum 50, no. 2 (2016). https://doi.org/ http://dx.doi.org/10.14421/asy-syir'ah.2016.502-03.

Fauza, N. 'Fikih Inklusif dalam Konteks Multikulturalisme Sosial Keagamaan Masyarakat Indonesia (Studi Pemikiran KH. Abdul Qodir AF)'. At-Tahdzib: Jurnal Studi Islam Dan Muamalah 6, no. 2 (2018): 94-114. http://ejournal.kopertais4.or.id/mataraman/ index.php/tahdzib/article/view/3575/2706.

Fuad, Mahsun. Hukum Islam Indonesia: Dari Nalar Partisipatoris Hingga Emansipatoris. Yogyakarta: LKiS, 2005.

Fukuyama, Mayumi. 'Society 5.0: Aiming for New Human Centered Society'. Japan Spotlight 27 (2018): 47-50. https://www.jef.or.jp/ journal/pdf/220th_Special_Article_02.pdf.

Gundaatmaja, Muhtar. Kontroversi Pemikiran Islam di Indonesia. Bandung: Rosdakarya, 993.

Hasan, Ahmad. The Early Development of Islamic Jurisprudence. Islamabad: Islamic Research Institute, 1970. 
I, Idri. 'Pengenalan Metodologi Filosofis dalam Kajian Fikih Budaya dan Sosial'. KARSA: Journal of Social and Islamic Culture 20, no. 2 (2013): 165-75. https://doi.org/https://doi.org/10.19105/karsa .v20i2.40.

Idris, Muhammad Ahnu, Taufik Taufik, and Bahrur Rosi. "Dakwah Pembebasan" Perspektif KH. MA. Sahal Mahfudh dalam Buku "Nuansa Fiqih Sosial"'. Ulumuna: Jurnal Studi Keislaman 6, no. 1 (15 June 2020): 35-52. https://doi.org/10.36420/JU.V6I1.3702.

Iskandar, Azwar, Bayu Taufiq Possumah, and Khaerul Aqbar. 'Peran Ekonomi dan Keuangan Sosial Islam Saat Pandemi Covid-19'. Salam: Jurnal Sosial Dan Budaya Syar-I 7, no. 7 (25 May 2020): 625-38. https://doi.org/10.15408/SJSBS.V7I7.15544.

Khaeruman, B. 'Al-Qaradawi dan Orientasi Pemikiran Hukum Islam Untuk Menjawab Tuntutan Perubahan Sosial'. Jurnal Wawasan: Jurnal Ilmiah Agama dan Sosial Budaya 1, no. 2 (2016): 227-38. https://doi.org/https://doi.org/10.15575/jw.v1i2.740.

Khan, M. Fahim. 'Fiqh Foundations of the Theory of Islamic Economics: A Survey of Selected Contemporary Writings on Economics Relevant Subjects of Fiqh'. In Theoretical Foundations of Islamic Economics, edited by Habib Ahmed, 1st ed., 59-85. Jeddah: Islamic Development Bank Islamic Reseacrh and TrainingInstitute, 2002. http://eprc.sbu.ac.ir/File/Book/ Theoretical foundations of islamic economics_47566.pdf.

Mahfudz, Muhammad Ahmad Sahal. Nuansa Fikih Sosial. Yogyakarta: LKis, 1994.

Maḥmașānī, Șubhī. Falsafah al-Tashrī’ fí al-Islām. Beirut: Dār al-'Ilm, 1961.

Mahrussilah, Mohammad. 'Fikih Sosial Kiai Sahal Mahfudh: Pengembangan Kemandirian Ekonomi Pesantren dan Masyarakat'. Jurnal Al Mizan 2, no. 2 (2018). https://ejurnal. iiq.ac.id/index.php/almizan/article/view/37/23.

Manan, Abdul. Aspek-Aspek Pengubah Hukum. Jakarta: Kecana, 2006.

Mas'ud, Muhammad Khalid. 'Ikhtilaf al-Fuqaha: Diversity in Fiqh as a Social Construction'. Musawa, 2009. https://arabic.musawah.org/ sites/default/files/Wanted-MKM-EN.pdf.

Mas'udi, Masdar Farid. Agama Keadilan: Risalah Zakat (Pajak) dalam Islam. Jakarta: LP3M, 1991. 
Arbanur Rasyid

Masruhan. 'Pemikiran Kyai NU Tentang Relasi Agama dan Negara'. Jurnal Al-Qanun 12, no. 1 (2009). https://doi.org/https://doi.org/ 10.15642/alqanun.2009.12.1.78-105.

Misrawi, Zuhairi. Menggugat Tradisi: Pergulatan Pemikiran Anak Muda NU. Jakarta: Kompas-P3M, 2004.

Mubarok, Jaih. Sejarah dan Perkembangan Hukum Islam. Bandung: Rosdakarya, 2001.

Muhammad. Dialog dengan Kiai Ali Yafie. Yogyakarta: IRCiSoD, 2020.

Muin, Abd, Mohd Adib, Shuhairimi Abdullah, and Azizah Che Omar. The Fiqh Method in Islamic Social Entrepreneurship: An Introduction. Islamic De. Singapore: Springer, 2019.

Muin, M.A. Abd, S. Abdullah, and A.C. Omar. The Fiqh Method in Islamic Social Entrepreneurship an Introduction in Islamic Development Management. Singgapore: Spinger, n.d.

Nizar, Moh. Metode Penelitian. Bogor: Ghalia Indonesia, 2005.

Nugroho, A. 'Rekontruksi Pemikiran Fikih: Mengembangkan Fikih Progresif-Revolusioner'. Al-Manahij: Jurnal Kajian Hukum Islam 9, no. 1 (n.d.): 1-20.

Qomar, Mujammil. Nu "Liberal": Dari Tradisionalisme Ahlussunnah ke Universalisme Islam. Bandung: Mizan, 2002.

Raharja, Handry Yoga. 'Relevansi Pancasila Era Industry 4.0 Dan Society 5.0 di Pendidikan Tinggi Vokasi'. Journal of Digital Education, Communication, and Arts (Deca) 2, no. 1 (2019): 11-20. https:// doi.org/10.30871/deca.v2i1.1311.

Rahmat, Jamal D. Wacana Baru Fiqih Sosial 70 Tahun KH. Ali Yafie. Bandung: Mizan, 1997.

Ramadhan, Tariq. Menjadi Modern Bersama Islam: Islam, Barat, dan Tantangan Modernitas. Bandung: Teraju Mizan, 2003.

Rofiq, Ahmad. Fikih Kontekstual: Dari Normatif ke Pemaknaan Sosial. Yogyakarta: Pustaka Pelajar, 2012.

Rusli, A. B. 'Nalar Ushul Fiqh KH. Sahal Mahfudh dalam Wacana Islam Indonesia'. Potret Pemikiran 22, no. 2 (2018). http://dx. doi.org/10.30984/pp.v22i2.785.

Sanrego, Y. D., and M Taufik. Fiqih Tamkin: Membangun Modal Sosial dalam Mewujudkan Khairu Ummah. Jakarta: Qisthi Press, 2016. 
Santoso, S. Konsep Corporate Social Responsibility dalam Perspektif Konvensional dan Fiqh Sosial. Tulunggaung: State Islamic Institute of Tulungagung, 2016.

Al-Shāfi'ī, Muhammad Ibn Idrīs. Al-Umm. 1st ed. Beirut: Dār al-Kutub al'Ilmiyyah, 2009.

Shiroishi, Yoshihiro, Kunio Uchiyama, and Norihiro Suzuki. 'Society 5.0: For Human Security And Well-Being'. Computer 51, no. 7 (2018): 91-95.

https://doi.org/https://doi.ieeecomputersociety.org/10.1109/M C.2018.3011041.

Skobelev, O.P., and S. Yu Borovik. 'On the Way from Industry 4.0 to Industry 5.0; from Digital Manufacturing to Digital Society'. Industry 4.0 2, no. 6 (2017): 307-11. https://stumejournals.com/ journals/i4/2017/6/307.full.pdf.

Sopyan, Y. 'Corporate Social Responsibility (CSR) sebagai Implementasi Fikih Sosial untuk Pemberdayaan Masyarakat'. AHKAM: Jurnal Ilmu Syariah 14, no. 1 (2014). http://dx.doi.org/10.15408/ajis. v14i1.1253.

Syatar, Abdul Syatar Abdul, Muhammad Majdy Amiruddin, Arif Rahman, and Islamul Haq. 'Darurat Moderasi Beragama di Tengah Pandemi Corona Virus Desease 2019 (Covid-19)'. KURIOSITAS: Media Komunikasi Sosial dan Keagamaan 13, no. 1 (2 June 2020): 1-13. https://doi.org/10.35905/KUR.V13I1.1376.

Syukur, A. 'Revitalisasi Ilmu Fiqh di Pesantren: Agenda Memperkuat Kontribusi Terhadap Ekonomi Islam di Indonesia'. Qawãnïn: Journal of Economic Syaria Law 2, no. 2 (2018). https://doi.org/https://doi.org/10.30762/q.v2i2.1043.

Umam, Khotibul. 'Legislasi Fikih Ekonomi Perbankan: Sinkronisasi Peran Dewan Syariah Nasional dan Komite Perbankan Syariah'. Mimbar Hukum 24, no. 2 (2012): 357-75. https://doi.org/ 10.22146/JMH.16139.

Wahid, Abdurrahman. Islam Kosmopolitan: Nilai-Nilai Indonesia dan Tranfromasi Kebudayaan. Jakarta: The Institute, 2007.

Yafie, Ali. Menggagas Fikih Sosial. Bandung: Mizan, 1994.

Al-Zarqā, Ahmad Muhammad. Sharh al-Qawā'id al-Fiqhiyah. Dār alQalam, 1938. 
Arbanur Rasyid

Zubaedi. 'Membangun Fikih yang Berorientasi Sosial: Dialektika Fikih dengan Realitas Empirik Masyarakat'. Al-Jami'ah 44, no. 2 (2006). https://doi.org/https://doi.org/10.14421/ajis.2006.442.429452.

Zubaidi. Pemberdayaan Masyarakat Berbasis Pesantren: Kontribusi Fikih Sosial Sahal Mahfudz dalam Perubahan Nilai-Nilai Pesantren. Yogyakarta: Pustaka Pelajar, 2007. 